\title{
LES INTERACTIONS ENTRE LA REPRODUCTION ET LA BIOLOGIE DES POPULATIONS CHEZ LES MONOGĖNES GYRODACTYLIDAE : REVUE
}

\author{
P. D. HARRIS \\ Department of Adult Education, University of Nottingham, University Park, Nottingham \\ NG7 2RD, UK.
}

\section{RÉSUMÉ}

Les Gyrodactylidae sont des Monogènes vivipares, les embryons se développent de manière emboitée dans l'utérus maternel. Les premier et deuxième individus fils se développent sans auto, ni fécondation croisée ; seuls les troisième et suivants peuvent se développer sexuellement. L'importance relative de la reproduction sexuée, dépend de la structure d'âge de la population et de la mortalité. Chez Macrogyrodactylus polypteri, le développement postnatal de l'appareil génital femelle facilite la fécondation croisée chez tous les individus suivant la seconde naissance. La reproduction asexuée maximise la croissance de la population mais la sexualité intervient régulièrement. Gyrdicotylus gallieni, qui parasite la bouche de Xenopus laevis, présente une croissance exceptionnellement lente de la population et les populations parasites sont surtout composées d'individus âgés et sexuellement matures. Isancistrum subulatae, parasite du Calmar Alloteuthis subulata, forme d'importantes populations, mais leur croissance est probablement lente, et la structure d'âge suggère que la sexualité est courante. Chez Gyrodactylus, plusieurs stratégies existent. Gyrodactylus turnbulli, chez les Guppis, a une courte durée de vie et manifeste une mortalité spécifique croissant exponentiellement avec l'âge, de telle sorte que moins d'un pour cent survivent assez longtemps pour donner une troisième naissance. La reproduction est principalement asexuée mais le sexe intervient dans les populations de très fortes densités. Dans la nature la reproduction asexuée prédomine sans doute et cette espèce peut être considérée comme cycliquement parthénogénétique. Chez le saumon, Gyrodactylus salaris, présente des mortalités faibles et $10-15 \%$ des survivants se reproduisent sexuellement. Des individus fécondés sont trouvés même dans les faibles infestations et la sexualité est habituelle dans la biologie de cette espèce. Chez Gasterosteus aculeatus, $G$. gasterostei présente à $15^{\circ}$ une mortalité semblable à celle de G. turnbulli, mais à $10^{\circ}$ la mortalité augmente moins vite avec l'âge. Les données, en populations naturelles, suggèrent que la sexualité est rare chez cette espèce. La sexualité peut être rare chez plusieurs espèces de Gyrodactylus, mais dans les populations naturelles de $G$. arcuatus une phase de croissance des populations a été observée à la suite d'une intervention probable de la sexualité. Ceci était très localisé, sur moins d'un mois, et n'a pas eu lieu, en un second site, trois kilomètres en aval.

Les stratégies de la reproduction sexuée peuvent être correlées avec les variations morphologiques et la spécificité parasitaire.

Les espèces sexuées peuvent être plus variables et montrent moins d'hétérogéneité entre les populations que les espèces à reproduction asexuée. Les formes sexuées apparaissent aussi plus tolérantes quant au choix de leur hôte. La double barrière de la spécificité parasitaire et de la reproduction asexuée peut être importante dans la prévention de l'hybridation entre populations génétiquement distinctes de Gyrodactylidae, ce qui maintient la diversité. L'impact potentiel de l'homme sur la biologie de la reproduction et l'évolution des Gyrodactylidae est discuté. 


\title{
INTERACTIONS BETWEEN REPRODUCTION AND POPULATION BIOLOGY IN GYRODACTYLID MONOGENEANS-A REVIEW.
}

\begin{abstract}
Gyrodactylid monogeneans are viviparous, embryos developing within each other inside the mothers uterus. First- and second-born daughters develop without self- or crossfertilisation, and only the 3rd and subsequent daughters can develop sexually. The relative importance of sexual reproduction depends on population age structure and mortality. In Macrogyrodactylus polypteri, post-natal development of the female reproductive system facilitates cross-insemination in all post-second birth individuals. Asexual reproduction maximises population growth, but sex occurs regularly. Gyrdicotylus gallieni, from the mouth of Xenopus laevis, has unusually slow population growth, and infections are composed largely of older, sexually mature individuals. Isancistrum subulatae, from the squid Alloteuthis subulata, forms very large populations, but growth is probably slow and the age structure suggests that sex is common. Within Gyrodactylus, several strategies exist. Gyrodactylus turnbulli on guppies is short lived, experiencing exponentially increasing age specific mortality which results in less than $1 \%$ surviving to give birth a third time. Reproduction is primarily asexual, but at high population densities sex is seen. In the field, asexual reproduction probably predominates, and this species can be regarded as a cyclic parthenogen. Gyrodactylus salaris, on salmon, experiences low mortality and $10-15 \%$ of individuals survive to reproduce sexually. Inseminated individuals are found, even in light infections, and sex forms a normal part of the biology of this species. G. gasterostei, from Gasterosteus aculeatus, has a mortality at $15^{\circ} \mathrm{C}$ resembling that of $\mathrm{G}$. turnbulli, but at $10^{\circ} \mathrm{C}$ mortality increases less rapidly with age. Data from natural populations suggest that sex is rare in this species. Sex may be rare in many Gyrodactylus species, but in a natural population of $G$. arcuatus a phase of population growth was observed when sex may have occurred. This was very local, lasting less than one month and not taking place at a second site, $3 \mathrm{~km}$ downstream. Sexual strategies can be correlated with morphological variation and host specificity. Sexual species may be more variable, and show less heterogeneity between populations than the possible asexual species. The sexual forms also appear more catholic in their host choice. The twin barriers of host specificity and asexual reproduction may be important in preventing hybridisation between genetically distinct gyrodactylid stocks, maintaining diversity. The potential impact of Man on gyrodactylid reproductive biology and evolution is discussed.
\end{abstract}

\section{INTRODUCTION}

Gyrodactylus and other lower monogeneans are remarkable for their species richness. Over 400 species of Gyrodactylus are known, and some areas, for example the deep sea and the tropics, have barely been sampled for these organisms. Questions concerning the speciation of this diverse group are therefore of general interest, and the processes involved deserve wider attention from biologists. It is clear from the complex distribution patterns of gyrodactylids that speciation has not occurred in parallel with the host groups, as suggested for oviparous monogeneans (Llewellyn, 1965). Instead, Gyrodactylus is divided into species groups (Malmberg, 1970), some of which may reflect natural taxa and result from a single radiation. Although many species in a group may infect the same host family, suggesting phylogenetic radiation, ecological transfer to unrelated hosts is also well known (Bakke et al, 1992a). Thus, the $G$. wageneri group primarily infects cyprinids, but has also radiated onto sticklebacks, percids, and cottids sharing habitats with the primary hosts. At present, nothing is known of the circumstances whereby these radiations can arise.

When von Nordmann (1832) described Gyrodactylus elegans, he noted the presence of hooks within the body which he interpreted as part of the gut. Von Siebold (1849) corrected this, realising that Gyrodactylus is viviparous, and contains a developing embryo which in turn may contain another young embryo at an earlier stage of development, a phenomenon termed hyperviviparity by Cohen (1977). Gyrodactylus was a popular subject for microscopy in the latter part of the 19th century and the results of Wagener (1860), 
Katheriner (1895, 1904), and Gille (1914), were remarkable considering the technology available. Research on gyrodactylid biology has lagged in the present century and has been replaced by numerous myths concerning their reproduction. This is partly due to nomenclatural problems, and to avoid further confusion the terms that I will use throughout this paper are listed in Table I.

Tableau I: Terminologie utilisée pour décrire la reproduction des Gyrodactyles.

Table I : Terminology used in describing gyrodactylid reproduction.

First-born daughter

Second-born daughter

Third-born daughter

F1 generation embryo

F2 generation embryo

F3 generation embryo (when visible)

Intra-embryonic generation

Embryo cluster
The first adult daughter born to a gyrodactylid, always develops as the intra-embryonic generation.

The second adult daughter born to gyrodactylid, develops from a large cell (oocyte ?) present within embryo.

The third adult daughter, this and all further daughters develop from oocytes.

The largest embryo contained within an adult fluke, will become the next daughter of the parent.

The next-largest embryo, will become the first-born daughter of the F1 embryo.

The smallest embryo, will become the first-born daughter of the F2 embryo.

The first-born daughter, which develops within the next oldest embryo of a cluster.

Group of embryos (F1, F2, F3) developing within each other within the parental uterus.

The first-born daughter originates from cells dividing mitotically at the centre of the embryo mass (Katheriner, 1895, 1904; Gille, 1914). This mitotic origin was supported by microdensitometric data (Harris, 1988a), which showed that all embryonic cells are diploid. Development of this daughter therefore appears to be by mitotic proliferation, similar to that of asexually reproducing digenean larvae (Haight, Davidson \& Pasternak, 1977; Whitfield \& Evans, 1983). Braun (1966) claimed to have observed meiotic cells at the centre of the embryo mass; these cells were not seen by either Katheriner $(1895,1904)$ or Gille (1914) in sectioned material, and have not been observed in spreads of embryonic cells (Harris, unpublished), although meiotic and mitotic chromosomes are easily differentiated (Gille, 1914; Harris, 1985a). The hypothesis (Braun, 1966) that the first-born daughter develops by extreme sexual paedogenesis is therefore considered unlikely on cytological grounds. Both first- and second-born daughters continue to be born in isolated flukes for many generations (Braun, 1966 ; Lester \& Adams, 1974 ; Scott, 1982 ; Jansen \& Bakke, 1991), without the possibility of cross- or self-fertilisation (Harris, 1985a), indicating that the processes involved in their formation do not involve sex. The origin of the second-born daughter clearly differs from that of the first-born daughter, and doubled meiotic chromosomes can be seen in the oocyte within a few minutes of its entry into the uterus (Harris, unpublished). Some form of meiotic parthenogenesis, appears to be involved in the development of this daughter. Evidence for sexual development was presented by Gille (1914), but no distinction was made between second-born and third-born daughters. 
However, as the second-born daughter is clearly parthenogenetic (Harris, unpublished), and as flukes of several species do not contain active spermatozoa until some time after the second-born daughter has started to develop (Harris, 1985a; Harris, 1989; Harris et al., 1993), sex is thought to be restricted to the third-born and subsequent daughters. Nevertheless, in some species, even the third and fourth daughters can be produced by isolated flukes (Jansen \& Bakke, 1991), and the processes by which this occurs are unknown.

In view of the evidence that unconventional reproductive mechanisms operate in gyrodactylids, I set out to review evidence from population and reproductive biology to establish possible breeding systems for these parasites. I then assess the importance of changes in breeding system for speciation. An understanding of the interactions between reproduction and genetic change in gyrodactylids is important because of their pathogenicity and increasing importance in managed natural fish populations (Halvorsen \& Hartwigsen, 1989; Bakke et al., 1992a). Man has had significant impact on gyrodactylid ecology by moving and manipulating fish stocks, and through doing so may influence gyrodactylid reproductive behaviour. The final part of this paper therefore examines the possibility of Man triggering genetic change in gyrodactylids through interference in aquatic ecosystems.

\section{GYRODACTYLID REPRODUCTIVE STRATEGIES}

Gyrodactylids are highly successful, infecting fishes from the tropics to the polar oceans. One genus (Gyrdicotylus) infects the oral cavity of the African clawed toad, while another (Isancistrum) has radiated onto cephalopod molluscs. It is not surprising, therefore, that a wide range of reproductive and population biologies are seen in the group. This is illustrated by Fig. 1, which shows differences in the size and persistence of infections of a range of gyrodactylids. Detailed case histories for these gyrodactylids are outlined below.

\section{Macrogyrodactylus polypteri}

This large gyrodactylid undergoes post-natal somatic development, the new-born $M$. polypteri being smaller than the adult and lacking a seminal receptacle and vagina (Malmberg, 1957b; Khalil, 1971). A detailed account of the population dynamics and reproductive biology of this parasite will be published elsewhere (Harris, in prep), and is summarised below. Infections on Polypterus senegalus persist for at least 9 months (Fig $1 \mathrm{~A})$, growing very rapidly initially before being limited by a host response. At their peak, populations contain several hundred individuals, but following the response dwindle to less than 20. This correlates with observations of wild fishes, which bear light infections of this parasite (Khalil, 1970). The host reaction results in the detachment of flukes from the fish, as described for Gyrodactylus alexanderi by Lester \& Adams (1974), which survive attached to the substrate for a few days. The host reaction may also suppress reproduction in addition to increasing detachment. All flukes older than the second birth had a seminal receptacle and had been inseminated (Fig. 2A). Copulation was regularly observed, and the highly mobile flukes moved readily over the skin of the fish in search of partners. Thus $M$. polypteri is essentially a sexual species, which utilises asexual reproduction to rapidly increase in abundance when a fish is first colonised.

\section{Gyrdicotylus gallieni}

This gyrodactylid, from the mouth of Xenopus laevis, has been studied by Harris \& Tinsley (1987). It has the slowest reproductive rate of any gyrodactylid (Fig. 1B), but accidental dislodgement is rare. A possible host response is manifested (Fig. 1B) after toads have been infected for circa 3 months. The parasite is rare in the wild (Harris \& Tinsley, 1987 ), and, as almost $60 \%$ of infections are made up of single worms, asexual reproduction would appear essential for its persistence. Populations of this species contain less than $20 \%$ pre-1st birth individuals (Harris \& Tinsley, 1987; Fig 2C), suggesting that G. gallieni is long lived, and reproduces sexually. Data on insemination are lacking, and it is not clear how single worm infections can be maintained when composed of older, sexual individuals. 

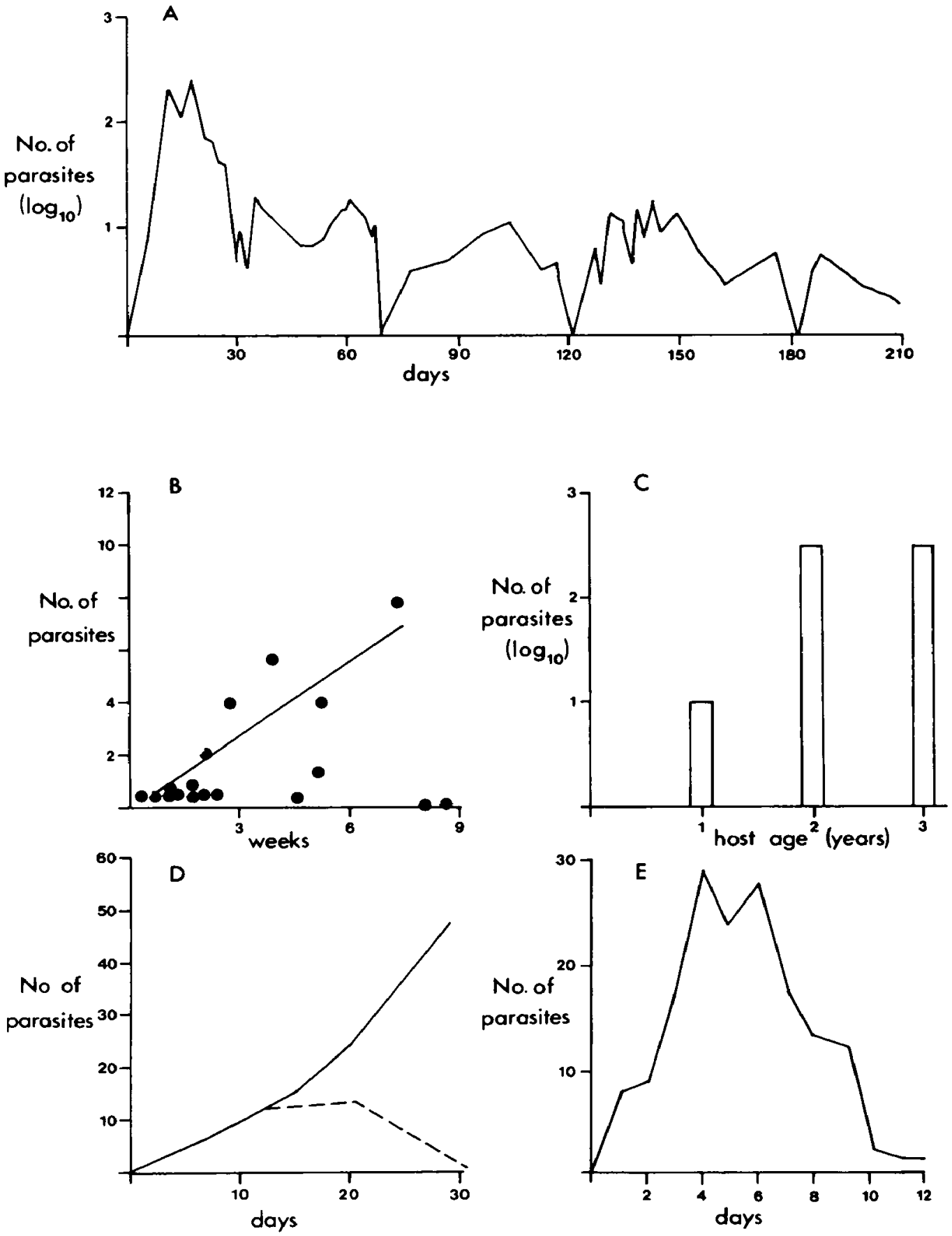

Figure 1 : Modèles d'infestation par des Gyrodactyles chez différents hôtes.

Figure 1 : Patterns of gyrodactylid infection on a variety of different hosts.

A. Macrogyrodactylus polypteri. Long term infection of a single Polypterus senegalus maintained at $25^{\circ} \mathrm{C}$ (Harris, unpublished). Note logarithmic scale.

B. Gyrdicotylus gallieniinfections from Xenopus laevis. Each point represents number of parasites found at autopsy in a toad previously infected with a single parasite. Line is regression for points up to $80 \mathrm{~d}$. Note two toads after $80 \mathrm{~d}$, known to be infected, which had lost infections by autopsy (from Harris \& Tinsley, 1987).

C. Isancistrum subulatae infections on Alloteuthis subulata. Note logarithmic scale. Recalculated from Llewellyn (1984).

D. Gyrodactylus salaris on saimon. Solid line, infections derived from a single fluke on Norwegian fishes. Dashed line, on Baltic races of salmon. After Bakke et al. (1990).

E. Gyrodactylus turnbulli on guppies. After Harris (1988b). 

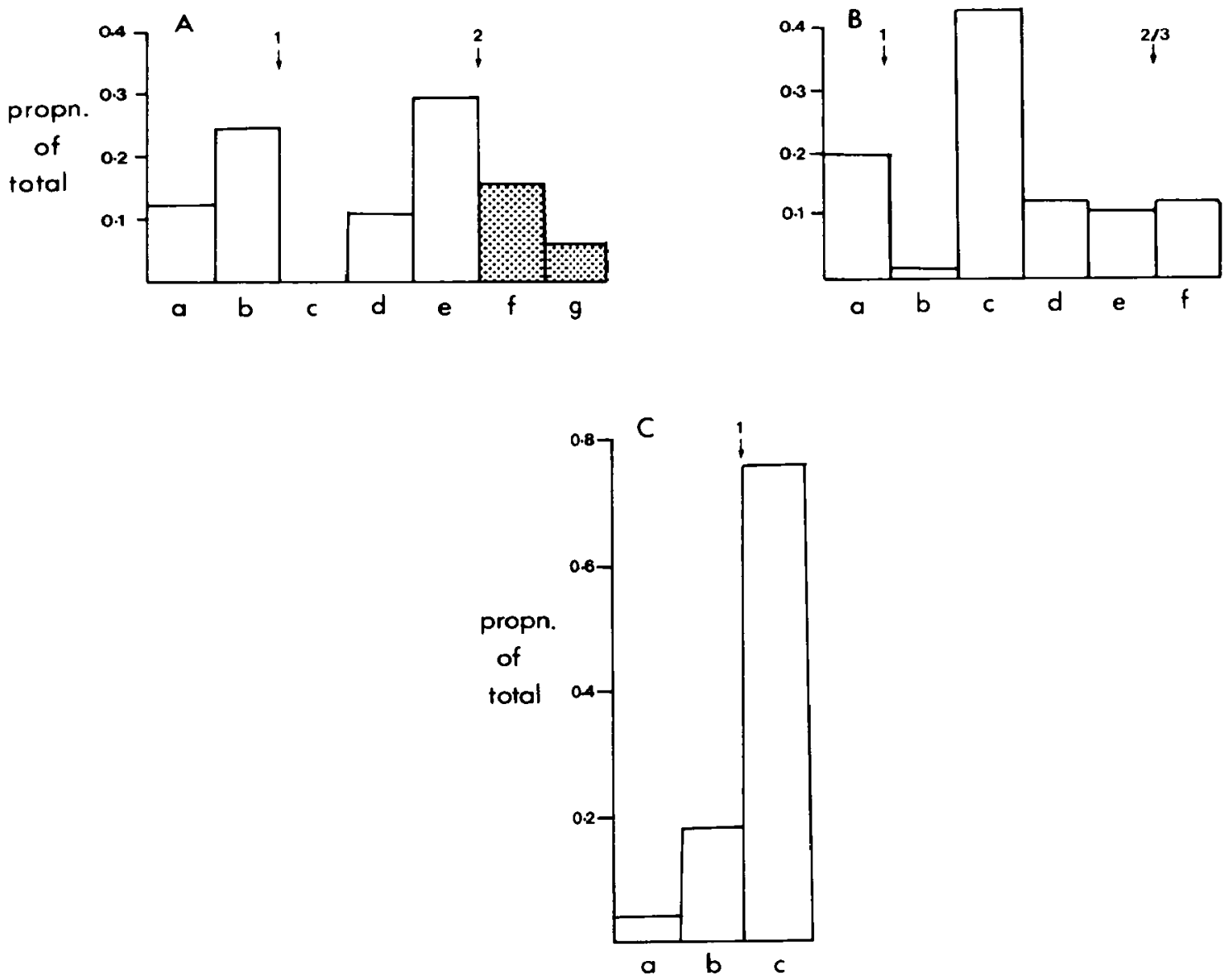

Figure 2 : Structures d'âge des populations chez trois genres de Gyrodactyles.

Figure 2 : Age structure of populations from three gyrodactylid genera.

A. Macrogyrodactylus polypteribased on specimens collected from the fishes kept in the same conditions as fig. 1A. a, new born flukes, no penis; $b$, no penis, large embryo, gut pigmented ; $c$, no penis, fluke immediately post-first birth, no embryo ; $d$, penis, small embryo, seminal receptacle undeveloped ; e, penis, large embryo, seminal receptacle undeveloped; $t$, penis, small embryo, seminal receptacle present, post-second birth ; $g$, penis, large embryo, seminal receptacle. Hatched area indicates proportion inseminated.

B. Isancistrum subulatae collected from Alloteuthis subulata, Plymouth 1984. Stage a, new-born flukes, no penis, large embryo ; b, no penis, empty uterus or very small embryo, immediately post-1st birth ; $c$, penis developed, embryo made up of mass of undifferentiated cells ; $d$, penis developed, embryo with marginal hook rudiments ; e, penis, fully developed embryo, immediately pre-2nd or 3rd birth; $f$, penis present, uterus empty, immediately post-2nd or 3rd birth.

C. Gyrdicotylus gallieni, based on populations recovered from experimental and naturally infected Xenopus laevis. a, no penis, embryo small, new-born ; $b$, no penis, large embryo, pre-1st birth ; c, penis, post-1st birth. After Harris \& Tinsley (1987). 


\section{Isancistrum subulatae}

This aberrant gyrodactylid, from the arms of the squid Alloteuthis subulata, has been studied by Llewellyn (1984), and additional material was collected in 1984 for determination of population structure. This parasite probably infects the squid during mating (Llewellyn, 1984), and populations grow slowly (Fig. 1C), attaining sizes of several thousand individuals in older squid (Llewellyn, 1984). The parasites are densely crowded onto the tentacles of the squid and do not appear to be limited by a host reaction. The population contains few new-born or pre-1st birth flukes (Fig. 2B), suggesting that this is a long-lived species which reproduces sexually.

\section{The genus Gyrodactylus}

Gyrodactylus is the largest viviparous genus and exhibits diverse reproductive strategies. The most thoroughly studied species are Gyrodactylus turnbulli on guppies (Scott, 1982; Scott \& Anderson, 1984; Harris, 1988b, 1989; Harris \& Lyles, 1992) and Gyrodactylus salaris on salmon (Bakke et al., 1990, 1992a; Harris et al., 1993). For both of these species population behaviour can be combined with observations on population structure and reproductive biology. Additional data are also presented from previously unpublished experiments (Harris, 1982) for species of the $G$. wageneri complex from Eurasian freshwater fishes.

\section{Calculating gyrodactylid mortality}

Gyrodactylid age can be estimated by the stage of development of the penis, the embryo and the testis (Harris, 1985a, 1989; Harris et al., 1993), and allows population structure and age-specific mortality patterns to be analysed. Theoretically it is possible, knowing age structure and population growth rate, and the age-specific fecundity of the species, to calculate a complete age-specific mortality schedule (Deevey, 1947). This has proved impossible in practice because post-1st, post-2nd or post-3rd birth flukes which contain a large embryo, all appear identical. The most reliably distinguished age classes are the pre-1st birth/new-born category, which have an advanced embryo but lack a penis, the immediately post-1st birth category, which lack a penis and have an empty uterus or an embryo consisting of at most a few cells, and the post-2nd or post-3rd birth individuals which have a penis but in which the uterus is empty or contains a very small embryo (Harris, 1985a). The use of population age structures must therefore be interpreted with caution although they can be used with more confidence where data on detached flukes is also available. Detached flukes, which in the natural environment would almost certainly die, can be recovered from the sediment of aquaria containing infected fishes, and allow an estimation of the age of fluke death.

An alternative approach has been to follow the fate of a cohort of parasites in singleworm infections throughout their lifetime, recording their age at death and using this to construct a life table (Scott, 1982). However, this approach can introduce artefacts associated with repeated anaesthesia and handling, and cannot reveal density- dependent effects on the age-specific mortality schedule.

This paper compares both approaches for G. turnbulli, and then applies the age structure technique to the other species discussed.

\section{Gyrodactylus turnbulli}

This short-lived species gives birth two or three times in a life span of $7 \mathrm{~d}$ (Scott, 1982). Infestations peak 10-12 days post-infection and disappear after 20d (Fig. 1E) following a host reaction (Scott \& Anderson, 1984; Harris, 1988b). At $25^{\circ} \mathrm{C}$ the parasites experience high, exponentially increasing mortality throughout their life time. Scott (1982) calculated this mortality as an average daily per capita rate of 0.24 , but the exponential pattern resulted in survival of $5 \mathrm{~d}$ old flukes being much poorer than that of $1 \mathrm{~d}$ old flukes. Reanalysis of age structure data (Harris, 1989) shows that populations contain almost $50 \%$ pre-first birth flukes, which at $25^{\circ} \mathrm{C}$ are less than $1 \mathrm{~d}$ old. It is impossible to reconcile observed reproductive rates with this large proportion of new-born flukes if any linear 
A

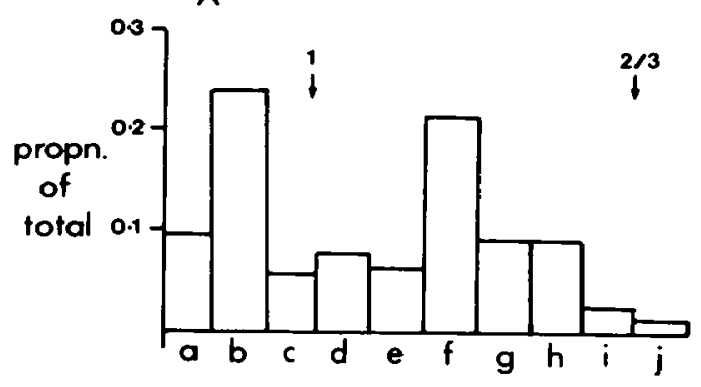

C

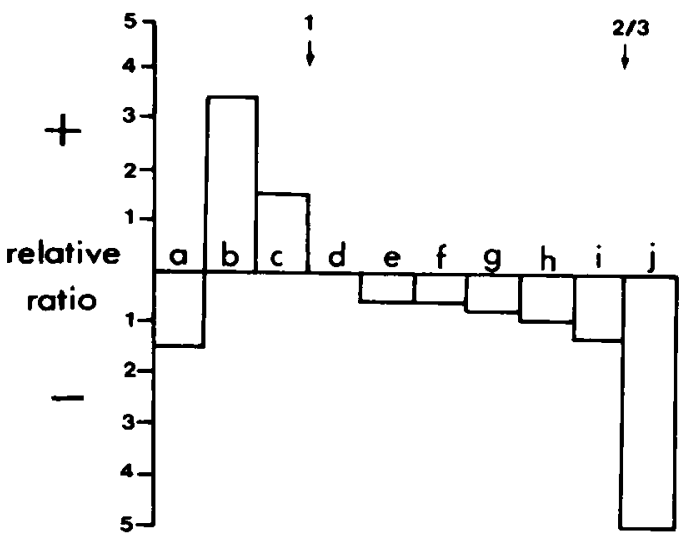

B

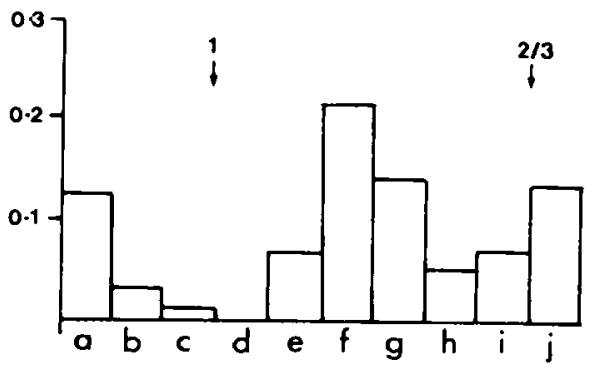

D

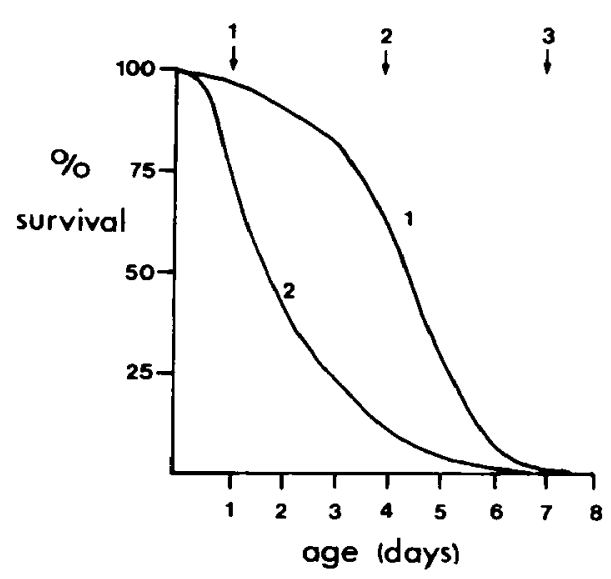

Figure 3 : Les différents stades de développement dans des populations de Gyrodactylus turnbulli parasite de la peau de Poecilia reticulata à $25^{\circ} \mathrm{C}$ dans les conditions environnementales décrites par Harris (1988b).

Figure 3 : Distribution of developmental stages in populations of Gyrodactylus turnbulli from the skin of Poecilia reticulata at $25^{\circ} \mathrm{C}$ in experimental populations described by Harris (1988b).

A. $a$, new born fluke, embryos with marginal hook rudiments; $b$, new-born fluke, embryo with hamulus rudiments up to shafts half full length; $c$, Pre-1st birth fluke, embryo with shafts half length up to fully developed; $d$, immediately post-first birth fluke, uterus empty or containing few macromeres; e, Post-1st, 2nd or 3rd birth fluke, embryo an undifferentiated mass of small cells; $f$, Post 1 st, 2 nd or 3rd birth fluke, embryo with marginal hook rudiments; $g$, Post 1st, 2nd or 3rd birth fluke, embryo with hamulus point rudiments; $h$, Post 1st, 2nd or 3rd birth fluke, embryo with hamulus shafts up to half full length; $i$, Post 1st, 2 nd or 3rd birth fluke, shafts half length up to fully developed; $j$, Post 2 nd or 3rd birth fluke, male reproductive system fully functional, uterus empty.

B. Distribution of developmental stages in flukes recovered from sediment in experimental aquaria.

C. ratio of proportion of each stage on skin: proportion of same stage in sediment. Positive ratio, enriched on fish, negative ratio, enriched in sediment.

D. Survivorship curves for G. turnbulli. (1) survivorship calculated from Scott's (1982) data for a cohort from single worm infections. (2), survivorship calculated from age structure data from experiments of Harris (1988b, 1989), using Scott's (1982) fecundity schedule, to satisfy the proportion in age group $1=0.47$, the ratio of this stage on fish to proportion in sediment $=1.67$. and population growth rate $=0.02$. Age at which each daughter is born marked by arrowheads. 
mortality model is postulated, suggesting that this species does indeed experience exponentially increasing mortality. When the relative abundance of each age class of flukes attached to the fish and detached in the sediment are compared (Fig. 3A,B,C), further evidence for this is obtained. New-born flukes are underrepresented amongst the detached parasites, and subsequent age groups become relatively increasingly abundant, until the oldest age class, post-2nd or 3rd birth flukes with a functional male system and no embryo, are 5 times more abundant amongst the detached parasites. The youngest age group, newborn flukes with an $\mathrm{F} 1$ embryo at the marginal hook rudiment stage, is also overrepresented in the detached parasites, dramatically so when compared with the next age class, which is three times as common in the attached population. These very young flukes appear to be near-term abortions, which may originate from dying, detached flukes, but some were found attached, suggesting that they may have been born in situ but experienced high mortality through physiological immaturity. A mortality schedule which satisfies the proportion of newborn flukes in the parasite population, the ratio of new-born flukes on the fish to the proportion of this stage detached, and the population growth rate (Fig 4D) does increase exponentially with parasite age, but suggests higher mortality of young and middle aged flukes than Scott's (1982) pattern. This pattern is applicable to a G. turnbulli suprapopulation which was growing only slowly, prior to a downturn, and suggests that increased mortality is mediated primarily through loss of younger and middle aged flukes.

During the course of infections the parasite population shows characteristic changes in distribution on the fish (Harris, 1988b). Initially parasites are widely spaced on the pectoral and caudal fins, the result of chance contacts with transmitting parasites. They move slowly onto the peduncle, where a dense population builds up 6-7d after infection. A reverse migration takes place as the infection declines (Harris, 1988b). Copulation takes place in $G$. turnbulli infections and is associated primarily with the peak phase when parasites are crowded onto the peduncle (Harris, 1989). Copulation is dependent upon crowding, and as there is a correlation between peak infection size and the number of parasites colonising the fish (Harris, 1989), it occurs during phases of epidemic population growth. When the parasite is scarce, sex is unlikely to occur (Harris, 1989). Additionally, the high, exponential mortality of the parasite ensures that few flukes survive to give birth for a third, sexual time. Only a small proportion (c.30\%) of the older, potentially sexual individuals have been inseminated, even in densely crowded populations in which copulation had been observed (Harris, 1989), further suggesting that sexual reproduction is comparatively rare. This species appears to be predominantly asexual,reproducing sexually only during occasional phases of epidemic population growth. Field studies support this hypothesis, showing that natural populations of $G$. turnbulli are generally small and contain a large proportion of pre-1st birth individuals (Harris \& Lyles, 1992).

\section{Gyrodactylus salaris}

This parasite causes an important disease of Atlantic salmon (Salmo salar) in Norway (Halvorsen \& Hartwigsen, 1989 ; Bakke et al, 1992) and is unusual for its variable morphology (Malmberg, 1987; Mo, 1991), wide host range (Bakke et al, 1991, 1992a,b) and pathogenicity. The failure of Norwegian salmon to respond to infection (Bakke et al, 1990) results in parasite populations numbering in their thousands (Jansen \& Bakke, 1993), presenting opportunities for sexual reproduction. The parasite has a low daily mortality at $13^{\circ} \mathrm{C} ; 20 \%$ of flukes may survive to give birth a third time and $10 \%$ may go on to give birth 4 times (Jansen \& Bakke, 1991). Harris et al. (1993), using population structure data, confirmed the low mortality measured from isolated flukes by Jansen \& Bakke (1991), and demonstrated the routine occurrence of insemination, even in light infections. Only older flukes (which had a functional male system) had ben inseminated, which is further evidence that the first two daughters of a fluke are produced asexually (Harris et al., 1993).

\section{The Gyrodactylus wageneri species complex}

This group of at least 30 almost identical species infects Eurasian freshwater fishes (Malmberg, 1957a, 1970; Ergens, 1965; Glaser, 1974; Harris, 1985b). Laboratory observations of $G$. gasterostei from Gasterosteus aculeatus are available (Harris, 1982) and are supplemented with data for this species and for $G$. pungitii from Pungitius pungitius from field populations. 

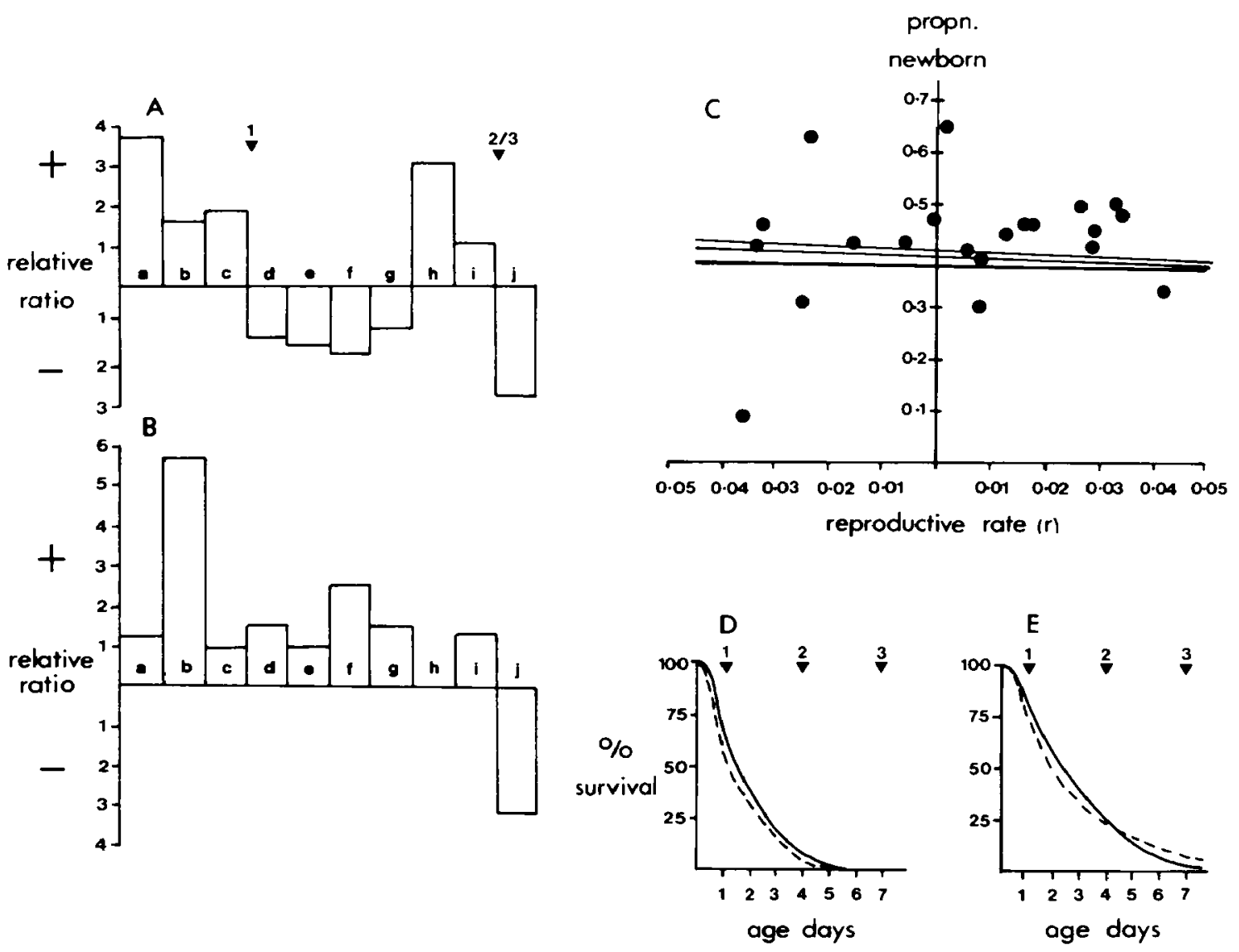

Figure 4 : Modèles de survie et de mortalité chez Gyrodactylus gasterostei.

Figure 4 : Survivorship and mortality patterns for Gyrodactylus gasterostei

A. Ratio, proportion of each developmental stage on skin to proportion of each stage detached in sediment, from population growth experiments (Harris, 1982) at $15^{\circ} \mathrm{C}$.

B. Ratio, proportion of each developmental stage on skin to proportion of each stage in sediment for flukes held at $10^{\circ} \mathrm{C}$. a, new-born flukes, no penis, hamulus rudiments one third full length; b, no penis, hamulus rudiments one-third to two-thirds in length;c, no penis, embryo with hamulus rudiments two-thirds full length up to fully grown; d, penis developing, uterus empty, immediately post first-birth; e, penis, small, undifferentiated embryo; $f$, penis, embryo with marginal hook rudiments; $g$, penis, embryo with hamulus rudiments up to one third full length; $h$, penis, embryo with hamulus rudiments one-third to two-thirds full length; $i$, penis, embryo with hamulus rudiments two thirds full length up to fully grown; j, penis, no embryo.

C. Comparison of observed proportion of pre-1st birth flukes in G. gasterostei populations from the river Ver, St Albans, southern England, at times when average weekly water temperature was $15^{\circ} \mathrm{C}(\bullet)$, compared with predictions based on fecundity at $15^{\circ} \mathrm{C}$ observed in laboratory experiments (Harris, 1982). Heavy line, proportion of new-born flukes at each reproductive rate assuming a linear mortality rate (no increase with age). Lighter lines, proportion predicted when mortality increases exponentially with age.

D. Survivorship curve based on on mortality predicted from simulation when $r=-0.07$ (lower end of range observed in nature).

E, Survivorship based on predicted mortality when $r=+0.10$ (upper end of observed range). Dashed lines, assuming constant mortality model, solid lines, assuming exponentially increasing mortality model. Age at which each daughter is born marked with arrowheads. 
The fecundity of Gyrodactylus gasterostei varies with temperature in a manner similar to that described for $G$. salaris (Jansen \& Bakke, 1991) and $G$. alexanderi (Lester \& Adams, 1974). In a series of experiments (Harris, 1980a; 1982), population growth, age structure and the distribution of developmental stages in flukes recovered from the tank sediment, were recorded. These data show a slightly different mortality pattern to $G$. turnbulli (Fig 4A, B). At $15{ }^{\circ} \mathrm{C}$ the relative abundance of each stage in the attached parasite population and amongst the detached parasites is similar to that for $G$. turnbulli, except that post-1st birth stages containing a large embryo are underepresented in the detached parasites. On the other hand, all post-1st birth stages containing a small embryo are enriched in the detached flukes, and the most abundant group are the old (post-2nd and 3rd) birth individuals with an empty uterus. Observations on attached flukes at $15^{\circ} \mathrm{C}$ (Harris, 1982 ; briefly reported in Harris, 1980b) suggested an increase in parasite activity when the embryo was small, which may result in the increased risk of detachment of these flukes. At $10^{\circ} \mathrm{C}$ the absence of any exponential component of mortality is more obvious (Fig. 4B), and the mortality may resemble more closely the constant pattern of $G$. salaris.

In natural populations of $G$. gasterostei and $G$. pungitii in the river Ver, southern England, the proportion of new-born flukes was high $(0.406 \pm 0.014, n=99$ for G. gasterostei; $0.506 \pm 0.011, n=50$ for $G$. pungitii), with the proportion highest in spring, when populations were growing rapidly and lowest in autumn, when the populations were declining. Simulation of population growth at $15^{\circ} \mathrm{C}$ using the experimentally derived age specific fecundity schedule (Harris, 1982) showed that, over a wide range of reproductive rates, the proportion of new-born flukes is relatively constant (Fig. 4C), and little affected by the pattern of age specific mortality. Superimposition of age structure data from the river Ver during 1980 and 1981 , when water temperature was $15^{\circ} \mathrm{C}$ showed agreement for many samples for the predicted age structures, while other points suggest that other mortality/fecundity schedules can act during the infection at $15^{\circ} \mathrm{C}$. In particular, two samples in which the proportion of new-born flukes was 0.6 or greater were collected from samples of recently infected fry, at, or shortly after, their synchronous infections had reached maximum size and were being limited by a host reaction. A third sample, in which the proportion of new-born flukes was 0.09 , came from a population of fry following the host reaction, when the parasite population was declining rapidly and synchronously. Most of the remainder of the points fell within the range of predicted pre-1st birth proportions, with a tendency for the mortality to incline towards the exponentially increasing model at higher growth rates. Although mortality may be linear both at $15^{\circ} \mathrm{C}$ and at $10^{\circ} \mathrm{C}$ (data not shown), the growth rates of the $G$. gasterostei populations are so low relative to the maximum possible, that mortality must be very high, even in new-born flukes. Under these circumstances, sexual reproduction is unlikely, except at the highest growth rates (Fig 4,D, $E)$, and no evidence of sex in these species was obtained. No inseminated individuals of either $G$. pungitii or G. gasterostei have been found.

\section{Conditions favouring sexual reproduction in natural gyrodactylid populations}

As noted above, conditions favouring sexual reproduction in Gyrodactylus gasterostei and $G$. pungitii were not observed in a two year field study. However, evidence was obtained of one phase of population growth which could have resulted in sexual reproduction in $G$. arcuatus, which also infects Gasterosteus aculeatus in these habitats. $G$. arcuatus is generally restricted to the gill chamber of its host in southern England, although it can infect the entire body surface of sticklebacks in Scandinavia (Malmberg, 1970), and populations contain a high proportion of new-born and pre-1st birth flukes, suggesting a primarily asexual reproductive strategy. On one occasion, in August 1981, the $G$. arcuatus population on stickleback fry grew rapidly and the proportion of parasites on the skin increased (Fig. 5A). At a second survey site, $3 \mathrm{~km}$ downstream, this increase did not occur. The age structure of the parasite population on the skin and the gills differed; the gill population contained many new-born and pre-1st birth flukes and resembled that seen before and after the epidemic (Fig 5 B,C,D). The skin population however, was enriched in flukes with small embryos, and in old flukes with a functional male system and no embryo in utero. The skin population appeared to consist of mobile flukes dispersing to other hosts, and its structure was such that copulation and sexual reproduction could have been occurring. 

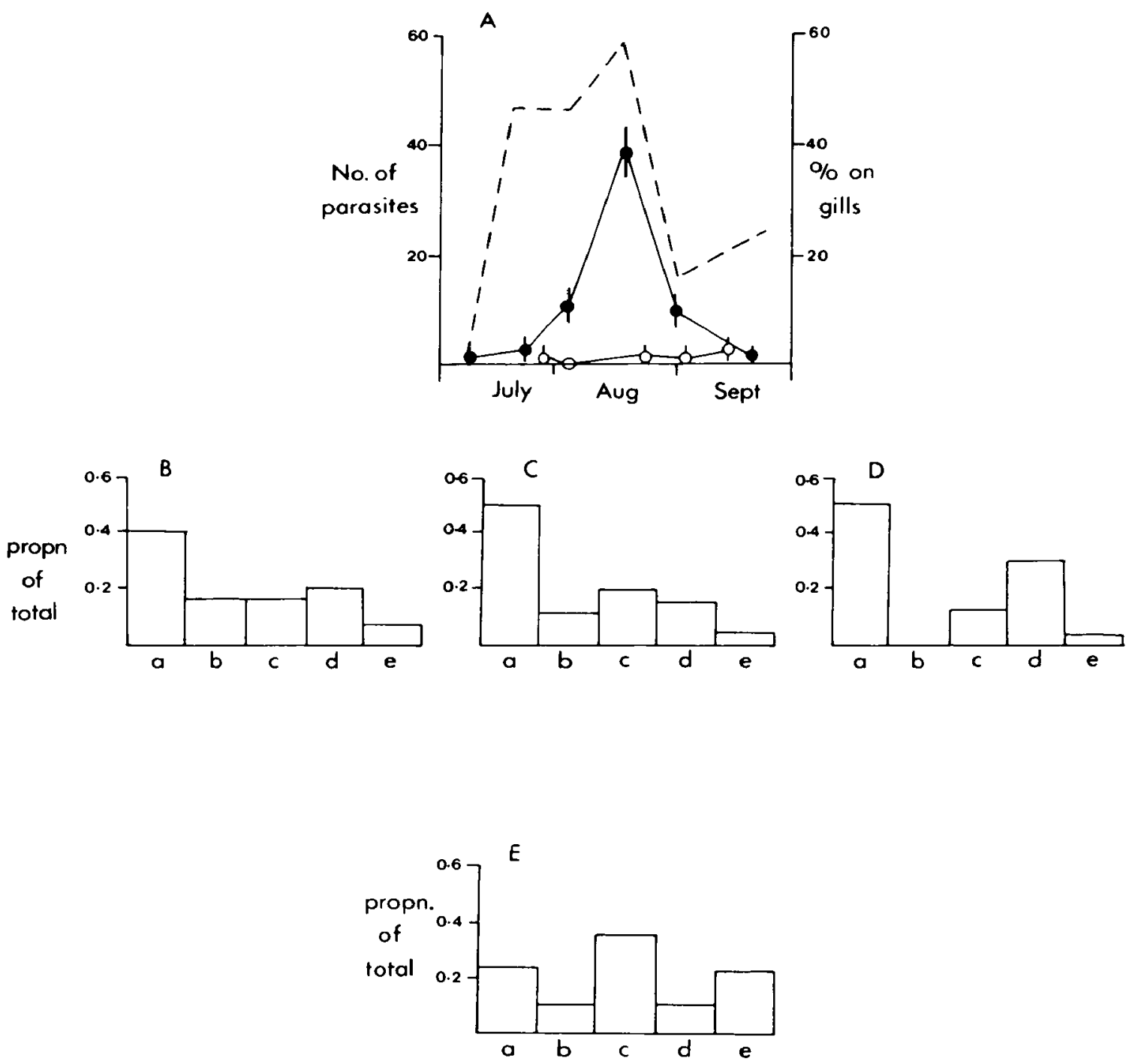

Figure 5 : Déroulement d'une épidémie de Gyrodactylus arcuatus dans une population naturelle de Gasterosteus aculeatus durant laquelle est intervenue la reproduction sexuée.

Figure 5 : Course of an epidemic of Gyrodactylus arcuatus in a natural population of Gasterosteus aculeatus, during which sexual reproduction may have been occurring

A. Course of epidemic in the river Ver, St Albans, southern England, in August 1981. (0) mean \pm S.E.m at Sopwell Mill. (o) mean \pm S.E.m at Park Street, 3km downstream. Hatched line, proportion of population on skin surface of fish. B,C,D,E, Population age distributions for $G$. arcuatus at Sopwell as the epidemic progressed. $a$, pre-1st birth flukes; $b$, immediately post-1st birth flukes; $c$, post $1 \mathrm{st}, 2$ nd or 3rd birth flukes with undifferentiated embryo in utero; $d$, post-1st, 2nd or 3rd birth flukes with large, differentiated embryo in utero; e, post 2nd or 3rd birth flukes with empty uterus.

B. population on gills and skin, July 1981.

C. population on gills, August 1981.

D. population on gills and skin, September, 1981.

E. Population on skin, August, 1981. Population on skin contains smaller proportion of pre 1 st birth individuals and less post-1st birth flukes with large embryos (d), but is enriched for post-1st birth flukes with small embryos (c) and post-2nd and 3rd birth individuals lacking an embryo (e). 


\section{DISCUSSION}

The first two daughters of a gyrodactylid develop without cross- or self-fertilisation (Braun, 1966 ; Lester \& Adams, 1974 ; Scott, 1982; Harris, 1985a; Jansen \& Bakke, 1991), and young flukes are not usually inseminated (Harris, 1989; Harris et al., 1993). Structures necessary for cross-fertilisation, and mature spermatozoa, are lacking until after flukes have given birth for the first time and the second oocyte has commenced development. This is compelling evidence that only the third and subsequent daughters may arise sexually. The consequences of this reproductive strategy in gyrodactylids, depends upon the population biology of the species concerned. In Macrogyrodactylus polypteri and Gyrodactylus salaris (Harris et al., 1993), asexual reproduction maximises population growth, but sex, as indicated by insemination, is frequent. In $G$. turnbulli (Harris, 1988a, 1989) and probably also $G$. arcuatus, asexual reproduction predominates but bouts of cross-fertilisation can occur when population conditions allow, and these species may be regarded as cyclic parthenogens. Finally, in the $G$. wageneri complex, particularly $G$. gasterostei and $G$. pungitii, sexual phases have never been observed, and the population structure suggests that they are very rare.

Gyrodactylids gain a considerable increase in reproductive rate through hyperviviparity, offsetting the bottleneck to reproductive output which is inevitable when progeny are retained in utero (Harris, 1983; Tinsley, 1983). This adaptation may have arisen by interpolation of a phase of asexual proliferation while the fluke is sexually immature to produce a crawling larva which already contains a developing embryo. The selective advantage of this adaptation would exert strong pressure for the diversion of resources to the intra-embryonic generation, rather than to later daughters, and could account for the progenesis of extant gyrodactylids (Harris, 1983). The relative importance of the first two births, particularly the first, is reinforced because diversion of resources to these daughters reduces the probability of the mother surviving to give birth again, and contributes to the high mortality experienced by flukes as they grow older. The selective pressure against sexual reproduction is considerable for, in addition to the familiar disadvantage that the sexual offspring inherits only half the genome of the mother that nourished it (Williams, 1975; Bell, 1982), the generation time for sexual offspring is much longer than that for the asexual progeny. Additionally resources must be diverted to sperm maturation, and the fluke must move to mate, increasing its risk of dislodgement. Finally the fitness of sexual offspring may be suboptimal relative to that of its parent when infecting the same host (Williams, 1975; Price, 1980). This may be very important for gyrodactylids with their very low fecundity, and may explain the observation that colonising flukes have often given birth at least once (Harris, 1989; Harris \& Tinsley, 1987 ; Harris et al., 1993), and have therefore left an identical copy of the genome on a host which is known to be suitable.

The genetic consequences of infrequent sex in some gyrodactylids are complex. The relative importance of the first-born daughter would lead to populations being made up of numerous asexual clones, in which the heterozygosity of the parent would be strictly preserved. Parthenogenesis in the second-born daughter, however, would lead to a gradual elimination of variation and an increase in homozygosity. Finally infrequent sex would restore heterozygosity and variation, and populations would contain a greater number of clones, the average size of which would be smaller. The complexity of population genetic structure in organisms with mixed reproductive strategies is considerable (Lynch, 1984 ; Hebert et al., 1988). One test of the hypothesis presented here is that variation would be greater in the sexual species than in those asexual forms in which clonal diversity is reduced. Some evidence for this can be obtained from morphological variation in gyrodactylids. The sexual genera Macrogyrodacty/us and Isancistrum have not been studied sufficently to establish the limits to variation, but Gyrdicoty/us is relatively variable (Tinsley et al., 1993), with the variance of hamulus dimensions exceeding $10 \%$ of the mean. Within Gyrodactylus, G. salaris is highly variable (Malmberg, 1987; Mo, 1991), with the variance of hamulus dimensions being $5-15 \%$ of the mean, while within the $G$. wageneri group it is typically less than $5 \%$ of the mean (Ergens, 1965; Harris, 1985b). The cyclic species $G$. turnbulli and $G$. arcuatus are intermediate, with variance ranging from 5$10 \%$ of the mean. Another prediction is that heterogeneity between populations would be considerable (Hebert et al, 1988). This can be clearly seen in Gyrodactylus arcuatus, which shows considerable differences between populations even after allowance is made for the 
effects of water temperature (Fig. 6). The variation in G. arcuatus, and its American counterpart $G$. avalonia, is so great that four taxa (G. aculeati Malmberg, 1970; G. lairdi Hanek \& Threlfall, 1970 ; G. memorialis Hanek \& Threlfall, 1970 and G. terranovae Hanek \& Threlfall, 1970) have been described and subsequently synonymised with it (Cone \& Wiles, $1983 a$ ), and the status of $G$. avalonia is unclear because variation across the range of $G$. arcuatus exceeds the limits used in separating the species. Nevertheless there is no doubt that all forms of $G$. arcuatus/avalonia belong to the same species or group of sibling species, and this variation may be due to clonal diversity.

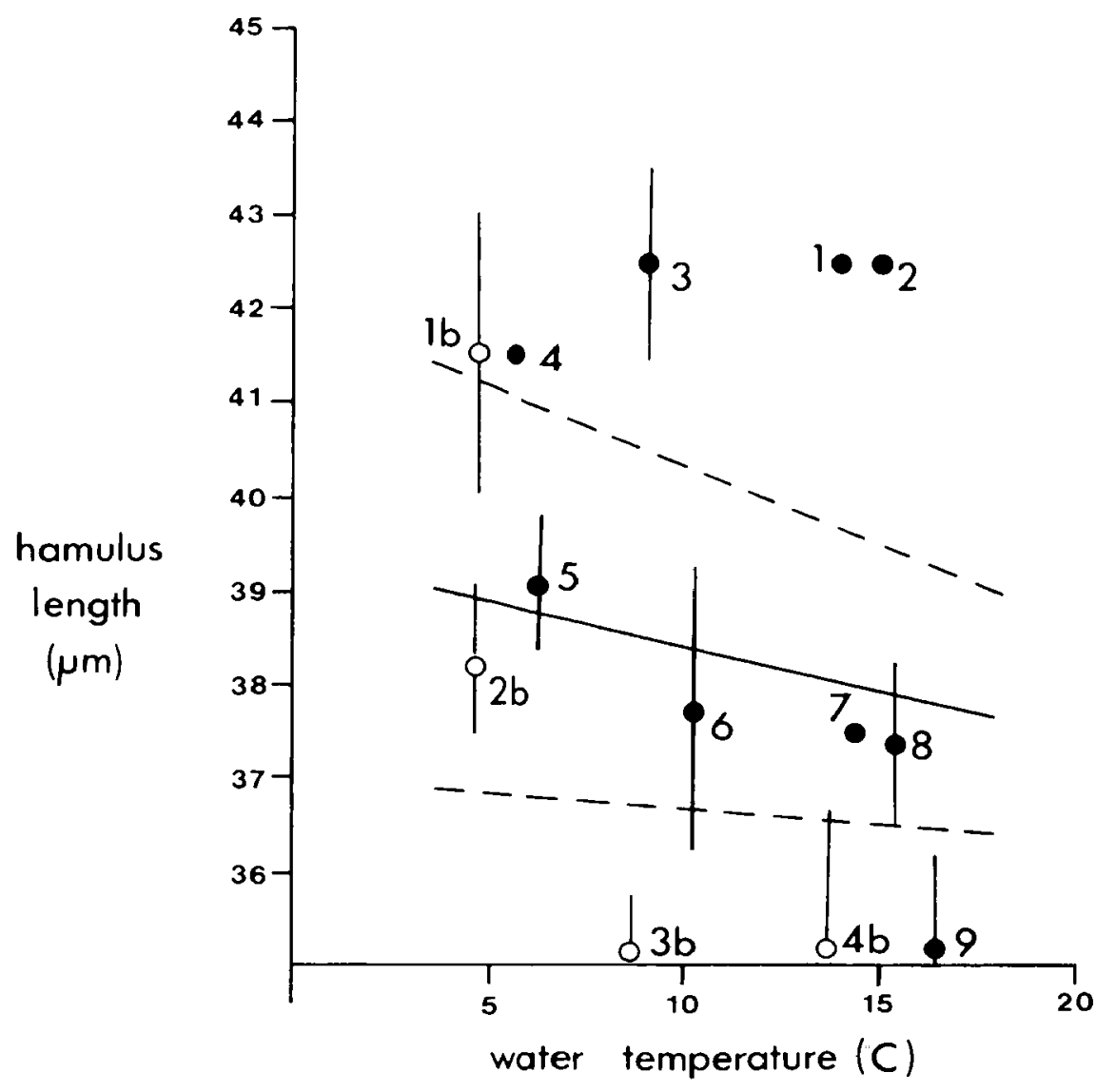

Figure 6 : Variations de longueur des hamulis dans les populations naturelles de $G$. arcuatus en basse Bretagne.

Figure 6 : Variation in hamulus length in natural populations of G. arcuatus in lowland Britain.

Solid line, mean hamulus length for this species collected from the river Ver throughout 1980 , showing variation due to water temperature. Dashed lines, 1 standard deviation above and below the mean. (e) hamulus dimensions for other populations from freshwater;

1, River Cam, Cambridge;

2, Dollis brook, North London;

3, River Yar, Isle of Wight;

4, Baildon Moor Pond, Yorkshire;

5, Brecon-Abergavenny Canal, South Wales;

6, River Lea, Harpenden;

7, Grand Union Canal, Wembley, London;

8, Rogate, Hampshire;

9, River Arrow, Redditch, Worcestershire.

(o) hamulus dimensions for populations collected from brackish water; $1 \mathrm{~b}$, Drainage ditches, river Medway, Cuxton, Kent; 2b, Drainage ditches, river Thames, Allhallows, Kent; 3b, The Fleet, Dorset; 4b, The Wide Water, Sussex. 
A trait which must reflect genetic variation in gyrodactylids is host specificity. The sexual Macrogyrodactylus polypteri infects Polypterus species throughout western and northern Africa (Senegal, Malmberg, 1957b; Zaire, Prudhoe, 1957; Sudan, Khalil, 1970), without showing sufficient morphological variation to consider subdividing the taxon. Similarly, Gyrdicotylus gallieni infects Xenopus laevis subspecies throughout sub-saharan Africa (Tinsley, et al, 1993a) without showing significant morphological variation between populations. Within Gyrodactylus, complex patterns of speciation and host specificity are seen (Bakke et al, 1992a). Members of some species groups (e.g. the G. wageneri group) are narrowly host specific, while others, such as $G$. salaris are more catholic in their choice of hosts.

In the light of the extensive variation seen between populations of a single species such as Gyrodactylus arcuatus, it is necessary to consider the nature of taxa within the $G$. wageneri group, many of which differ by only slight morphological differences. While some species, such as $G$. pungitii and $G$. rogatensis show little variation, others, such as $G$. aphyae and $G$. pannonicus are much more variable (Malmberg, 1957a, 1970; Ergens, 1975), and measurements of British G. aphyae (Harris, 1985b) straddle those of European specimens of both species. This suggests that while some taxa within the $G$. wageneri group are well established, others may be more labile, and locally distinct clones may be grouped within existing species. Although no evidence for sex has been obtained for $G$. gasterostei or $G$. pungitii, copulation has been described in a $G$. wageneri species (probably G. gurleyi) from goldfish (Braun, 1966). The diversity of the $G$. wageneri complex is reminiscent of that seen in other parthenogenetic organisms, for example the mixture of cyclic and obligately parthenogenetic clones of Daphnia described by Hebert et al (1988).

Parthenogenesis may provide, with host specificity, a barrier to hybridisation between species. At least three mechanisms maintain host specificity (Bakke et al, 1992a). Two of these, physiological intolerance and the host reaction, operate post-invasively, after the parasite has infected a novel host, and cannot prevent hybridisation between gyrodactylids. The third mechanism, behavioural avoidance of unsuitable hosts (Harris, 1982; Tinsley et al, 1993b), prevents infection of novel hosts, but this too is leaky and would not by itself prevent introgression of gyrodactylid stocks. However, the reliance on asexual reproduction would reduce further the chance of hybridisation occurring. These twin mechanisms, host specificity and asexuality, may largely prevent hybridisation, and may be responsible for maintaining the diversity of gyrodactylids. The existence of fishes which cannot mount a host response (Madhavi \& Anderson, 1984) may be an important mechanism promoting the ocurrence of sexual reproduction when hosts mix. Fishes with these genotypes would be rapidly selected out of the host population, but provide a transient opportunity for exponential parasite population growth, facilitating sexual reproduction. When such hosts have been eliminated from the population, a return to asexual reproduction would then occur. A process of this type may be taking place on Atlantic salmon in Norway, and the intense selective pressure (Jansen \& Bakke, 1993) suggests that genetic resistance may soon appear. However, sexual reproduction in $G$. salaris occurs even at low parasite population densities (Harris et al., 1993), and this species may be a generalist which employs sexual reproduction to generate the genetic diversity needed for infection of such a wide host range.

If sexual reproduction can influence gyrodactylid speciation, and is, as argued above, under local and unstable environmental control, it is necessary to examine the role of Man in perturbing aquatic ecosystems. The introduction of gyrodactylids into new watersheds is well documented (Mizelle \& Kritsky, 1967; Cone \& Wiles, 1983b), but has in general caused few problems, because host specificity has prevented transfer to novel hosts. A possible case where problems have arisen is that of G. salaris in Norway, although evidence for an introduction in this case is equivocal (Halvorsen \& Hartwigsen, 1989). More disconcerting is the evidence, presented above, that gyrodactylid species are made up of a heterogenous collection of morphologically and genetically distinct populations, often only separated by a few miles. Mixing of hosts on a small scale, without intervening political boundaries, may be sufficient to increase gene flow between gyrodactylid populations and to trigger bouts of sexual reproduction and speciation. Furthermore, it is possible for Man to create situations where endemic, asexual gyrodactylids can exploit introduced populations of susceptible hosts and begin to reproduce sexually. For example, in Norway, the genetic diversity of 
salmonids has been considerably modified by exploitation and the release of stock derived from different localities (Skaala, 1992). It is also possible that pollution may suppress the host response (Pickering \& Pottinger, 1983, 1985), allowing gyrodactylid populations to increase to a point where sexual reproduction starts to occur. Much more information on the processes of sexual reproduction and speciation in gyrodactylids is needed, if further disastrous epidemics of these parasites in natural fish populations are to be avoided.

\section{ACKNOWLEDGEMENTS}

Much of my work on gyrodactylids was originally supported by a studentship and a post-doctoral fellowship funded by NERC. I am grateful to the two Jack's, Cohen and Llewellyn, for their influence on my ideas while at Birmingham. I would also like to acknowledge collaborations with Richard Tinsley (Gyrdicotylus), Tor Bakke (Gyrodactylus salaris), and Anna Marie Lyles (G. turnbulli), which have allowed me access to a much wider range of gyrodactylids than would otherwise be the case. Finally, I would like to thank Dave Campbell, who collected /sancistrum for me, and Jim Murray for providing wordprocessing facilities.

\section{REFERENCES}

BAKKE T.A., JANSEN, P.A. \& HANSEN, L.P. ,1990. Differences in the host resistance of Atlantic salmon (Salmo salar) stocks to the monogenean Gyrodactylus salaris Malmberg, 1957. J. Fish Biol., 37, 577-587.

BAKKE T.A., JANSEN, P.A., \& KENNEDY, C.R., 1991. The host specificity of Gyrodactylus salaris Malmberg, (Platyhelminthes, Monogenea): susceptibility of Oncorhynchus mykiss (Walbaum) under experimental conditions. J. Fish Biol., 39, 45-57.

BAKKE T.A., HARRIS, P.D., JANSEN, P.A., \& HANSEN, L.P., 1992a. Host specificity and dispersal strategy in gyrodactylid monogeneans with particular reference to Gyrodactylus salaris (Platyhelminthes, Monogenea). Dis. Aqu. Org., 13, 45-57.

BAKKE T.A., HARRIS, P.D. \& JANSEN, P.A., 1992b. The susceptibility of Salvelinus fontinalis (Mitchill) to Gyrodactylus salaris Malmberg (Platyhelminthes; Monogenea) under experimental conditions. J. Fish Biol., 41, 499-507.

BELL G. 1982. The Masterpiece of Nature : the evolution and genetics of sexuality. Croom Helm, London \& Canberra.

BRAUN E., 1966. Beitrage zur mikroskopischen Anatomie und Fortpflanzungsbiologie von Gyrodactylus wageneri von Nordmann, 1832. Z. Parasit., 28, 142-174.

COHEN J., 1977. Reproduction. Butterworth, London. $356 \mathrm{p}$

CONE, D.K., \& WILES, M., 1983a. The systematics and zoogeography of Gyrodactylus species (Monogenea) parasitizing gasterosteid fishes in North America. Can. J. Zool., 63, 956-960.

CONE D.K. \& WILES, M. 1983b. A redescription of Gyrodactylus gurleyi Price 1937 (Monogenea) with notes on species of Gyrodactylus parasitising goldfish in North America. Can. J. Zool., 61, 2932-2937.

DEEVEY E.S., 1947. Life tables for natural populations of animals. Quart. Rev. Biol., 22, 283-314.

ERGENS R., 1965. Die morphogenese der chitinoiden teile des haptors bei Gyrodacty/us tincae (Malmberg, 1956) Malmberg, 1964 und ihre morphologische metrische variabilitat. Z. Parasit., 26, 173-184.

ERGENS R., 1975. Contribution to the knowledge of the species Gyrodactylus aphyae Malmberg, 1957 and G. pannonicus Molnar, 1968 (Monogenoidea: Gyrodactylidae). V. Cesk. Spol. Zool., 34, 1-8.

GILLE K., 1914. Untersuchungen uber der Eiereifung, Befruchtung und Zellteilung von Gyrodactylus elegans von Nordman. Arch. Zellforsch., 12, 415-456. 
GLASER H.J., 1974. Sechs neue arten der Gyrodactylus wageneri gruppe (Monogenea, Gyrodactylidae), nebst bemerkugen, zur praeparation, determination, Terminologie und Wirtspezifistat. Zool. Anz., 192, 56-76.

HAIGHT M., DAVIDSON, D. \& PASTERNAK, J., 1977. Relationship between nuclear morphology and the phases of the cell cycle during cercarial development of the digenean trematode Trichobilharzia ocellata. J. Parasitol., 63, 267-273.

HALVORSEN O., \& HARTWIGSEN, R., 1989. A review of the biology and epidemiology of Gyrodactylus salaris. NINA Utredning 2, 1-14.

HARRIS P.D., 1980a. The effect of temperature on population growth of Gyrodactylus. Parasitol., 81 xxvi.

HARRIS P.D., 1980b. The behaviour of Gyrodactylus on living hosts. Proc. 3rd Europ.Multicol. Parasitol., Cambridge. p 97.

HARRIS P.D., 1982. Studies on the Gyrodactyloidea (Monogenea). Unpublished Ph.D. thesis, University of London.

HARRIS P.D., 1983. The morphology and life cycle of the oviparous Oogyrodactylus farlowellae gen. et sp. nov. (Monogenea, Gyrodactylidea). Parasitol., 87, 405-420.

HARRIS P. D., 1985a. Observations on the development of the male reproductive system in Gyrodacty/us gasterostei Glaser, 1974. Parasitol.,91, 519-529.

HARRIS P.D., 1986. Species of Gyrodactylus from poeciliid fishes with a description of Gyrodactylus turnbulli sp. nov. from the guppy Poecilia reticulata Peters. J. Nat. Hist., 20, 183-191.

HARRIS P.D., 1988a. Is gyrodactylid intra-embryonic reproduction sexual or asexual? evidence from Feulgen microdensitometry. Proc. 1st Int. Cong. Monogenea, Ceske Budejovice. Inst. Parasitol. Czech Acad. Sci. Ceske Budejovice, Czechoslovakia. p 17.

HARRIS P.D., 1988b. Changes in the site specificity of Gyrodactylus turnbulli Harris, 1986 (Monogenea) during infections of individual guppies (Poecilia reticulata Peters). Can. J. Zool., 66, 2854-2857.

HARRIS P.D., 1989. Interactions between population growth and sexual reproduction in the viviparous monogenean Gyrodactylus turnbulli Harris, 1986 from the guppy Poecilia reticulata Peters. Parasitol., 98, 245-251.

HARRIS P.D., JANSEN, P.A. \& BAKKE, T.A., 1993. The population age structure and reproductive biology of Gyrodactylus salaris. Submitted to Parasitology.

HARRIS P.D. \& TINSLEY, R.C., 1987. The biology of Gyrdicotylus gallieni (Gyrodactylidae), an unusual viviparous monogenean from the African clawed toad Xenopus laevis. J. Zool., Lond., 212, 325-346.

HARRIS P.D. \& LYLES, A-M., 1992. Infections of Gyrodactylus bullatarudis and G. turnbulli on guppies (Poecilia reticulata) in Trinidad. J. Parasitol., 78, 912-914.

HEBERT P.D.N., WARD, R.D. \& WEIDER, L.J., 1988. Clonal diversity patterns and breeding system variation in Daphnia pulex, an asexual sexual complex. Evol., 42, 147-159.

JANSEN P.A. \& BAKKE, T.A., 1991. Temperature dependent reproduction and survival of Gyrodactylus salaris Malmberg, 1957 (Platyhelminthes: Monogenea) on Atlantic salmon (Salmo salar L). Parasitol., 102, 105-112.

JANSEN P.A. \& BAKKE, T.A., 1993. Regulatory processes in the monogenean Gyrodactylus salaris Malmberg-Atlantic salmon (Salmo salar L.) association. 1. Field studies in south east Norway. Fish. res. in press.

KATHERINER L., 1895. Die gattung Gyrodactylus v. Nordmann Arb. Zoolog. Zootom. Inst., Wurzburg, 10, 127-164. 
KATHERINER L., 1904. Ueber der Entwicklung von Gyrodactylus elegans von Nordmann. Zool. Jahrb., Suppl., 7, 519-551.

KHALIL L.F., 1970. On the biology of Macrogyrodactylus polypteri, a monogenetic trematode on Polypterus senegalus. J. Helminthol., 44, 329-348.

LESTER R.J.G. \& ADAMS J.R., 1974. Gyrodactylus alexanderi: reproduction, mortality and effect on the host. Can. J. Zool. 52, 827-833.

LLEWELLYN J., 1965. The evolution of parasitic platyhelminthes. In 3rd Symp. B.S.P., Blackwell, Oxford.

LLEWELLYN J., 1984. The biology of Isancistrum subulatae n. sp., a monogenean parasite on the squid Alloteuthis subulata at Plymouth. J. Mar. Biol. Assn. U.K., 64, 285-302.

LYNCH M., 1984. The genetic structure of a cyclical parthenogen. Evol. 38, 186-203.

MADHAVI, R. \& ANDERSON R.M., 1985. Variability in the susceptibility of the fish host Poecilia reticulata, to infection with Gyrodactylus bullatarudis (Monogenea). Parasitol., 91, 531-544.

MALMBERG G., 1957a. Om forekomsten av Gyrodactylus pa svenska fiskar. Skrift. sodra sver. Fisk. Arrskr., 1956, 19-76.

MALMBERG, G., 1957b. On a new genus of monogenetic trematodes. Ark. Zool.,10, $317-$ 329.

MALMBERG G., 1970. The excretory system and marginal hooks as a basis for the systematics of Gyrodactylus. Ark. Zool., 23, 1-237.

MALMBERG G., 1987. Increased intraspecific divergence in Gyrodacty/us salaris resulting from genetic drift in fish farm populations. Abo Information 19, 33 (Proc. 13th Symp. Scand. Soc. Parasitol., Helsinki, Finland, June 12th-14th, 1987).

MIZELLE J.D. \& KRITSKY D.C., 1967. Studies on monogenetic trematodes XXXIII. New species of Gyrodactylus and a key to the North American species. Trans. Am. Micr. Soc., 86, 390-401.

MO T.A., 1991. Seasonal variations of opisthaptoral hard parts of Gyrodactylus salaris Malmberg, 1957 (Monogenea: Gyrodactylidae) on parr of atlantic salmon Salmo salar L. in the river Batnfjordselva, Norway. Syst. Parasitol. 19, 231-240.

NORDMANN A. von, 1832. Micrographische Beitrage von Naturgeschichte der wirbellosen Thiere, vol. 1 Berlin, $118 \mathrm{p}$.

PICKERING A.D., \& POTTINGER T.G., 1983. Seasonal and diel changes in plasma cortisol levels of the brown trout Salmo trutta. Gen. Comp. Endocrinol., 49, 232-239.

PICKERING A.D., \& POTTINGER T.G., 1985. Cortisol can increase the susceptibility of brown trout Salmo trutta L., to disease without reducing the white blood cell count. $J$. Fish Biol., 27, 611-619.

PRICE P.W., 1980. Evolutionary Biology of Parasites. Princeton University Press, Princeton.

PRUDHOE S., 1957. Trematoda. In G.F. de Witte (ed.), Expl. Parc Nat. I'Upemba Fasc., 48, Brussels p4-9.

SCOTT M.E. ,1982. Reproductive potential of Gyrodactylus bullatarudis on guppies (Poecilia reticulata). Parasitol., 85, 217-236.

SCOTT M.E. \& ANDERSON R,M., 1984. The population dynamics of Gyrodactylus bullatarudis with in laboratory populations of the fish host Poecilia reticulata. Parasitol., 89, 159-185.

SIEBOLD C.T. von, 1849. Gyrodactylus, ein ammenartiges Wesen. Z. wiss. Zool.,1, 347363.

SKAALA O., 1992. Genetic population structure of norwegian brown trout. J. Fish Biol. 41, $631-646$. 
TINSLEY R.C., 1983. Ovoviviparity in platyhelminth life cycles. Parasitol., 86, 161-196.

TINSLEY R.C., HARRIS P.D. \& JACKSON, J., 1993a. Species of Gyrdicotylus from Xenopus in Africa. Submitted to Systematic Parasitology.

TINSLEY R.C., HARRIS P.D., \& JACKSON J. 1993b. The host specificity of Gyrdicotylus gallieni from Xenopus laevis. Submitted to Systematic Parasitology.

WAGENER G.R., 1860. Ueber Gyrodactylus elegans von Nordmann. Arch. Anat. Physiol. wiss. Med. 768-797.

WHITFIELD P.J. \& EVANS N.A., 1983. Parthenogenesis and asexual multiplication amongst parasitic platyhelminths. Parasitol., 86, 121-160.

WILLIAMS G.C., 1975. Sex and evolution. Princeton, Princeton University press.

Since this paper was written, M.K. Jones \& I.D. Whittington (1992, Parasitology Research 78, 534-536) have published an electron micrograph showing spermatozoa surrounding the oocyte of an apparently pre-1st birth specimen of Gyrodactylus from goldfish. Furthermore, in May 1993, Tor Bakke and I observed a small number of spermatozoa within the oocyte of a pre-1st birth $G$. salris using TEM. The number of spermatozoa involved was very small, too few to be detected with the light microscope, and quite different from the normal result of cross-insemination, in which many spermatozoa can be seen in the seminal receptable. While these findings further complicate the development of the second-born daughter of gyrodactylids, they do not affect the principal conclusions of this paper, that the firt-born daughters, which develop asexually, are numerically most important in gyrodactylid populations, and that functional males are rare. Thereis also no doubt that development of the second-born daughter can proceed normally even in isolated flukes with no opportunities for self- or cross-fertilisation. Clearly, much remains to be discovered concerning gyrodactylid reproduction. 